\title{
ANALISA KUALITAS SISTEM INFORMASI MANAJEMEN MENGGUNAKAN FRAMEWORK COBIT 5 (STUDI KASUS PADA KANTOR DPRD KABUPATEN SIJUNJUNG)
}

\author{
Gushelmi $^{1}$, Mondra Neldi ${ }^{2}$,Yayan Septiadi ${ }^{3}$ \\ 1,2,3 Universitas Putra Indonesia YPTK Padang \\ email: gushelmi@upiyptk.ac.id \\ email : mondraneldi@gmail.com \\ email : septiadiyayan@gmail.com
}

\begin{abstract}
Information technology has significantly influenced and changed the way businesses are being managed and monitored today. Information technology has been used by many companies as a solution in facing and winning the competition. In line with that, a Cobit 5 framework by used program language PHP and MySQL database is needed to ensure that information technology implemented requires companies to maximize profits, information technology risks are managed appropriately and used responsibly. In order to achieve these objectives, careful and optimal planning, implementation, support, monitoring and evaluation are required. By applying the quality analysis of the management information system, employee satisfaction in using the existing system at the Sinjunjung DPRD can provide solutions in updating and improving the quality of the existing system.
\end{abstract}

Keywords: Cobit 4.1 framework, quality, analisys, PHP, MySQL

\begin{abstract}
Abstrak
Teknologi informasi secara signifikan telah mempengaruhi dan mengubah cara bisnis yang sedang dikelola dan dipantau saat ini. Teknologi informasi yang telah digunakan oleh banyak perusahaan sebagai salah satu solusi dalam menghadapi dan memenangkan persaingan. Sejalan dengan itu diperlukan suatu kerangka kerja Cobit 5 dengan bahasa pemrograman PHP dan Database MySQL untuk memastikan bahwa teknologi informasi yang diimplementasikan mengharuskan perusahaan dalam memaksimalkan keuntungan, resiko teknologi informasi dikelola dengan tepat dan digunakan secara bertanggung jawab. Guna mencapai tujuan dimaksud diperlukan perencanaan, implementasi, dukungan, pengawasan dan evaluasi yang matang dan optimal. Dengan diterapkan analisa kualitas sistem informasi manajemen kepuasan karyawan dalam menggunakan sistem yang ada pada DPRD Sinjunjung dapat memberikan solusi dalam memperbaharui dan meningkatkan kualitas sistem yang ada.
\end{abstract}

Kata Kunci : Kerangka kerja Cobit 5, Kualitas, Analisa, PHP, MySQL

\section{PENDAHULUAN}

Teknologi informasi secara signifikan telah mempengaruhi dan mengubah cara bisnis yang sedang dikelola dan dipantau saat ini (Hakim et al. 2014). Teknologi informasi yang telah digunakan oleh banyak perusahaan sebagai salah satu solusi dalam menghadapi dan memenangkan persaingan. Sejalan dengan itu diperlukan suatu kerangka kerja untuk memastikan bahwa teknologi informasi yang diimplementasikan mengharuskan perusahaan dalam memaksimalkan 
keuntungan, resiko teknologi informasi dikelola dengan tepat dan digunakan secara bertanggung jawab (Abdurahman 2018). Guna mencapai tujuan dimaksud diperlukan perencanaan, implementasi, dukungan, pengawasan dan evaluasi yang matang dan optimal (Andry Jeffry; Khotama, Michael; Chandra, Agustinus; Gunawan, Catherine Kurniadi 2018).

Dengan demikian kerugian-kerugian yang mungkin terjadi dapat diupayakan untuk dihindari. Kerugian dimaksud dapat terjadi dari kehilangan data, penyalahgunaan data, penyalahgunaan komputer, informasi yang tidak akurat karena kesalahan dalam pemrosesan data sehingga validitas data diragukan. Investasi yang telah dikeluarkan untuk perangkat keras dan perangkat lunak relatif mahal, tetapi tidak diikuti dengan nilai balik yang sepadan(Adolong et al. 2017),(Hadi \& Gushelmi 2021). Dengan demikian diperlukan suatu evaluasi teknologi informasi untuk menelusuri bagian mana saja yang harus diperbaiki sehingga tujuan kerja tercapai (Teknologi et al. 2021),(Hilmawan et al. 2015).

Kerangka kerja COBIT 5 mengidentifikasikan proses-proses teknologi informasi dalam 4 domain utama yaitu domain Planning \& Organise (PO), Acquire \& Implement (AI), Deliver \& Support (DS) dan Domain Monitor \& Evaluate (ME) . Domain Planning \& Organise (PO): mencakup strategi dan taktik serta perhatian pada identifikasi cara teknologi informasi dalam memberikan kontribusi terbaiknya pada pencapaian objektif bisnis. Domain Acquire \& Implement (AI) : mencakup realisasi, implementasi dan integrasi strategi teknologi informasi kedalam proses bisnis. Domain Deliver \& Support (DS): berhubungan dengan peyampaian dan dukungan layanan-layanan teknologi informasi. Domain Monitor \& Evaluate (ME) : mencakup pengawasan pada seluruh kendali-kendali yang diterapkan pada setiap proses teknologi informasi (Hapsari et al. 2018),(Fauzan, R., \& Latifah 2015),(Eva Zuraidah 2020) .

Berdasarkan hal tersebut diatas maka penulis melakukan penelitian pada tata kelola teknologi informasi di DPRD Kabupaten Sijunjuang dengan mengambil 2 domain yaitu DS dan ME karena domain PO dan AI berada di tingkat divisi masing-masing yang berada di kantor pusat

\section{METODE PENELITIAN}

Dalam melakukan penelitian agar mendapat hasil seperti yang diharapkan, maka diperlukan kerangka kerja penelitian, dimana kerangka penelitian yang dilakukan dapat dilihat pada Gambar 1 :

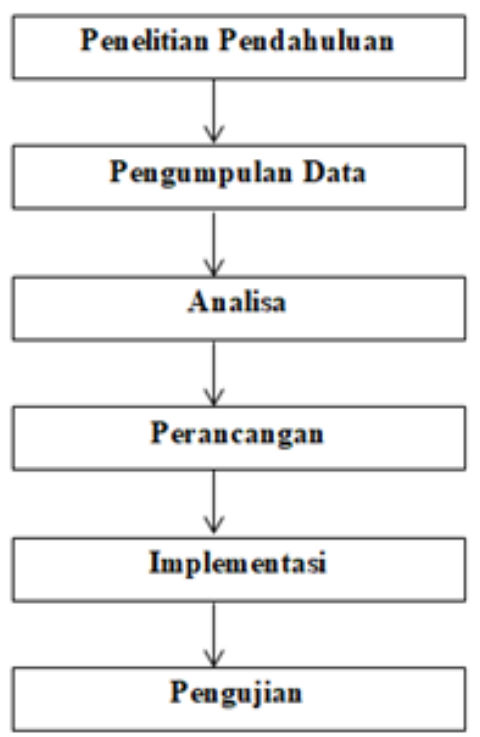

\section{Gambar 1. Kerangka Penelitian}

\section{Tahapan Penelitian}

Pada tahapan penelitian, penulis melakukan beberapa tahapan dalam penelitian sesuai dengan kerangka penelitian yang sudah dijelaskan pada Gambar 3.1.

\section{Penelitian Pendahuluan}


Penelitian pendahuluan merupakan langkah pertama dalam melakukan suatu penelitian dengan cara menganalisa terlebih dahulu masalah-masalah objek yang akan diolah. Mempelajari bagaimana objek tersebut bisa melakukan pemecahan masalahnya, faktor sekeliling lingkungan dan dampak dari objek tersebut.

Penelitian pendahuluan dapat memberikan bukti awal bahwa masalah yang akan kita teliti dilapangan benarbenar ada. Oleh sebab itu dibutuhkan waktu untuk pengambilan data, waktu penelitian, tempat penelitian, riset perpustakaan, dan penelitian laboratorium.

\section{Pengumpulan Data}

Dalam pelaksanaa penelitian ini dilakukan pengumpulan data dengan cara membagikan kuesioner, serta melakukan wawancara kepada kepada karyawan Adapun hal-hal yang berkaitan dalam melakukan pengumpulan data pada metodologi penelitian adalah sebagai berikut :

a. Penelitian Lapangan (Field Resarch)

Penelitian lapangan dilakukan langsung pada objek penelitian untuk mengumpulkan data primer dengan teknik pengumpulan data sebagai berikut :

1) Observasi

Pada tahap ini dilakukan pengamatan lapangan dengan cara melihat bagaimana Sistem dijalankan dan mempelajari kegunaan dari Sistem tersebut.

2) Wawancara (Interview)

Untuk mendapat data dan informasi dilakukan percakapan antara peneliti dengan responden sumber data.

3) Kuesioner

Pada tahapan ini dilakukan pengumpulan data dengan cara membagikan angket kuesioner

b. Penelitian Pustaka (library Research)

Penelitian ini dilakukan untuk mencari, mengumpulkan dan mempelajari data dari buku-buku, internet, serta literatur-literatur yang berhubungan dengan permasalahan yang dijadikan sebagai objek penelitian.

c. Penelitian Laboraturium ( Laboratory Research )

Penelitian laboraturium merupakan penelitian yang dilakukan dengan menggunakan komputer sebagai alat bantu dalam penerapan dan praktek langsung dalam menyelesaikan masalah, sehingga hasil yang dicapai dapat sesuai dengan yang diharapkan. Adapun perangkat keras (hadware) yang dipakai dalam penelitian ini, yaitu :

1) Laptop Asus

2) Processor AMD

3) Memory 8 GB

4) Flashdisk Sandisk 32 GB

Sedangkan perangkat lunak (software) yang digunakan dalam penelitian ini antara lain :

1) Sistem Operasi Windows 10

2) Microsoft Office 2013

3) MySQL Server

4) XAMMP Control Panel

\section{Analisa Dan Perancangan}

Di dalam proses analisa, terdapat tiga tahapan yang harus dilakukan. Adapaun tiga tahapan tersebut antara lain :

a. Analisa

Pada tahap analisa, penulis akan melakukan tiga tahapan yaitu Analisa Data, Analisa Proses dan Analisa Sistem

b. Perancangan

Tahapan perancangan ini, peneliti menggunakan Unified Modeling Language (UML) sebagai tools dalam menjelaskan alur analisa program, dimana UML yang digunakan yaitu : Use Case Diagram, Class Diagram, Activity Diagram, Sequence Diagram.

\section{Implementasi}

Implementasi merupakan tahap meletekkan sistem sehingga siap untuk dioperasikan. Aplikasi yang dirancang, diimplementasikan dengan menggunakan bahasa pemograman PHP dan Database 
MySQL sebagai alat bantu dalam melakukan proses pengolahan data hasil kuesioner untuk mengukur kualitas sistem pelayanan terhadap sistem yang ada pada DPRD Sijunjung,

\section{Pengujian}

Pengujian sistem merupakan tahap melakukan testing untuk mengetahui kesalahan dalam hasil pengukuran kualitas sistem. Pengujian terhadap sistem dilakukan untuk dapat mengukur kualitas sistem pelayanan terhadap karyawan yang ada pada DPRD Sijunjung.

\section{HASIL DAN PEMBAHASAN}

Hasil dan pembahasan adalah hasil dari pengamatan atau penelitian. Yang terdapat dalam teks ilmiah. Sebagai laporan observasi tentang penilaian terhadap sesuatu. Hasil pengamatan merupakan isi bagian yang penting dari teks ilmiah. Hasil pembahasan mempunyai sifat objektif atau subjektif. Hasil pembahasan sebagai pertimbangan atau acuan, untuk dijadikan sebagai sebuah teori. Hasil dari penelitian ini adalah pihak DPRD Sijunjung dapat memberikan kemudahan kepada pihak DPRD dalam proses evaluasi pelayanan sistem terhadap karyawan.

Analisa dengan menentukan nilai ratarata pada tiap kriteria dan bobot yang bergantung pada kepentingan maka hasil penelitian kualitas perangkat lunak yang diperoleh dari 18 responden dapat dilihat pada Tabel 1.

Tabel 1. Hasil Perhitungan Kuisoner

\begin{tabular}{|c|c|c|c|c|}
\hline NO & Indikator & Keterangan & Bobot & $\begin{array}{l}\text { Nilai } \\
\text { Kriteria }\end{array}$ \\
\hline 1 & $\begin{array}{c}\text { Operation } \\
\text { Correctness } \\
\text { (Ketetapan) } \\
0,3\end{array}$ & $\begin{array}{l}\text { a. Completeness } \\
\text { (Kelengkapan) } \\
\text { 1. Apakah aplikasi yang } \\
\text { ada pada DPRD } \\
\text { Sinjung telah } \\
\text { memberikan } \\
\text { kemudahan kepada } \\
\text { pihak karyawan } \\
\text { dalam proses kerja. }\end{array}$ & 0,4 & 4,88 \\
\hline
\end{tabular}

\begin{tabular}{|c|c|c|c|c|}
\hline & \multirow[t]{4}{*}{$\begin{array}{c}\text { Correctness } \\
\text { (Ketetapan) } \\
0,3\end{array}$} & $\begin{array}{l}\text { 2. Apakah semua menu- } \\
\text { menu yang ada pada } \\
\text { sistem tersebut telah } \\
\text { terancang dan di } \\
\text { guanakan dengan } \\
\text { baik }\end{array}$ & 0,4 & 4,44 \\
\hline & & $\begin{array}{l}\text { b. Consistensy } \\
\text { (Konsistensi) } \\
\text { 1. Apakah Fitur-fitur } \\
\text { didalam sistem sama } \\
\text { dengan menu-menu } \\
\text { yang lainnya }\end{array}$ & 0,3 & 4,16 \\
\hline & & $\begin{array}{llr}\text { 2. } & \text { Bahasa } & \text { yang } \\
& \text { digunakan } & \text { sudah } \\
& \text { konsisten di } & \text { setiap } \\
& \text { halamannya } & \\
\end{array}$ & 0,4 & 4,16 \\
\hline & & $\begin{array}{l}\text { c. Treaceability (Lacak) } \\
\text { Apakah pengguna dapat } \\
\text { mengakses sistem tersebut } \\
\text { kapan saja dan dimana } \\
\text { saja. }\end{array}$ & 0,4 & 4,33 \\
\hline \multirow[t]{6}{*}{2.} & \multirow[t]{6}{*}{$\begin{array}{c}\text { Usability } \\
\text { (Kegunaan) } \\
0,2\end{array}$} & $\begin{array}{l}\text { d. Communicativeness } \\
\text { (Komunikatif) } \\
\text { 1. Apakah bahasa } \\
\text { yang dijsajikan } \\
\text { dalam sistem dalam } \\
\text { di telaah dengan } \\
\text { baik }\end{array}$ & 0,4 & 4,44 \\
\hline & & $\begin{array}{ll}\text { 2. } & \text { Tulisan dari setiap } \\
\text { halaman } & \text { dapat } \\
\text { terbaca dengan jelas }\end{array}$ & 0,4 & 4,72 \\
\hline & & $\begin{array}{l}\text { e. Operability } \\
\text { (Operabilitas) } \\
\text { 1. Pilihan menu dan } \\
\text { tombol pada sistem } \\
\text { mudah dipahami }\end{array}$ & 0,4 & 4,5 \\
\hline & & $\begin{array}{ll}\text { 2. Pengguna mudah } \\
\text { mengerti dengan } \\
\text { system pengkodean } \\
\text { yang ada }\end{array}$ & 0,4 & 4,5 \\
\hline & & $\begin{array}{ll}\text { f. } & \text { Trainning (Pelatihan) } \\
\text { 1. } & \text { Pengguna baru } \\
& \text { dapat dengan } \\
& \text { mudah } \\
& \text { menggunakan } \\
& \text { sistem perkara } \\
& \text { online tersebut }\end{array}$ & 0,4 & 4,22 \\
\hline & & $\begin{array}{ll}\text { 2. Apakah ada sistem } \\
\text { yang diguanakan } \\
\text { memeiliki panduan }\end{array}$ & 0,4 & 4,27 \\
\hline \multirow[t]{2}{*}{3.} & \multirow[t]{2}{*}{$\begin{array}{c}\text { Integrity } \\
\text { (Integritas) } \\
0,3\end{array}$} & 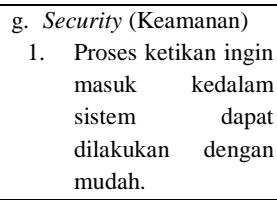 & 0,4 & 4,33 \\
\hline & & $\begin{array}{llr}\text { 2. } & \text { Aplikasi ini } & \text { dapat } \\
\text { mengontrol } & \text { akses } \\
\text { pengguna } & \text { dengan } \\
\text { membatasi } & \text { hak } \\
\text { akses } & \end{array}$ & 0,4 & 4,16 \\
\hline \multirow[t]{2}{*}{4.} & \multirow[t]{2}{*}{$\begin{array}{c}\text { Reliability } \\
\text { (Kehandala } \\
\mathrm{n}) \\
0,2\end{array}$} & $\begin{array}{l}\text { h. Accuration (Akurasi) } \\
\text { 1. Apakah aplikasi ini } \\
\text { dapat melakukan } \\
\text { pencarian data } \\
\text { sesuai data kunci. }\end{array}$ & 0,4 & 4,27 \\
\hline & & $\begin{array}{llr}\text { 2. Informasi dari } \\
\text { aplikasi ini akurat } \\
\text { dan bebas dari } \\
\text { kesalahan dalam } \\
\text { menggunakan } \\
\text { sistem }\end{array}$ & 0,4 & 4,22 \\
\hline
\end{tabular}




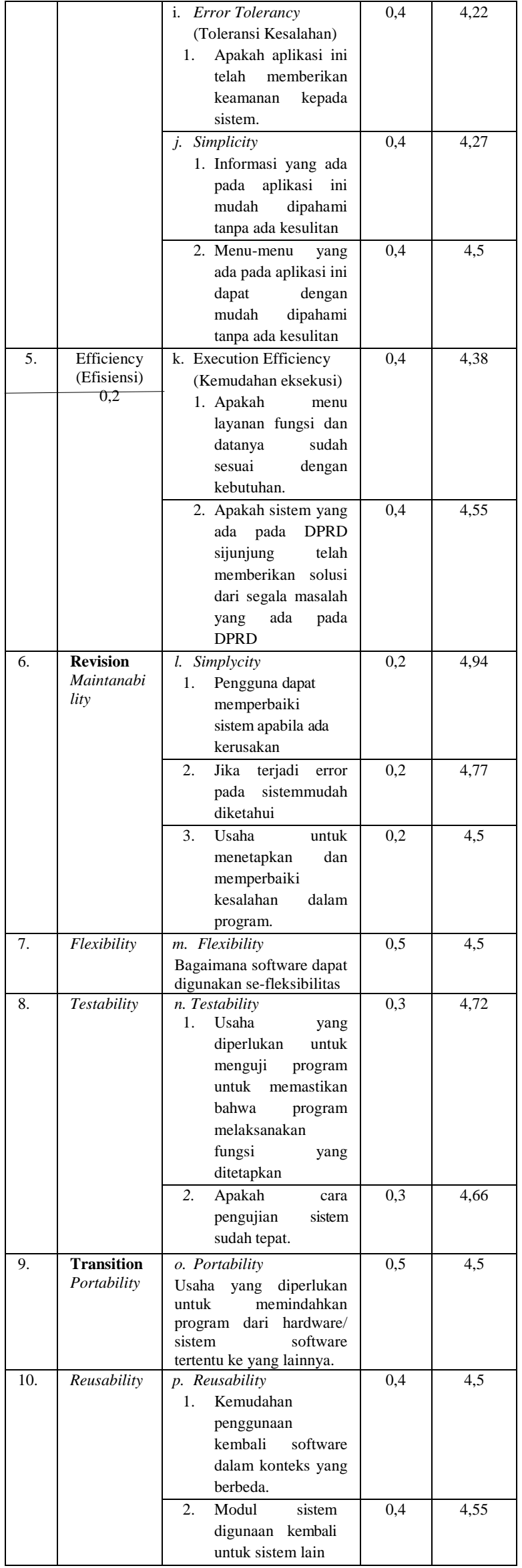

\begin{tabular}{|l|l|l|l|l|}
\hline 11. & $\begin{array}{l}\text { Interoperab } \\
\text { ility }\end{array}$ & $\begin{array}{l}\text { q. Interoperability sistem } \\
\text { Apakah } \\
\text { dapatbekerja } \\
\text { berdampingan dengan } \\
\text { perangkat lainnya tanpa } \\
\text { mengalami kesulitan }\end{array}$ & 0,5 & 4,72 \\
\hline
\end{tabular}

Dari hasil persentase yang didapat dari perhitungan nilai total Fa berdasarkan pada faktor kualitas yang ada pada Cobit 5 kemudian dibandingkan dengan skala likert, yaitu skala yang digunakan untuk mengukur sikap, pendapat, dan persepsi seseorang atau sekelompok orang tentang suatu kejadian. Pengelompokan tingkat persentase sesuai skala likert yaitu dapat dilihat pada tabel 2, maka dapat disimpulkan bahwa aplikasi sistem yang ada pada DPRD Sijunjung secara total berada pada level antar $81 \%$ - $100 \%$ $=92,59 \%$ dan termasuk dalam kategori sangat baik.

\section{Tabel 2. Hasil Perhitungan}

\begin{tabular}{|l|c|c|c|}
\hline No & Domain & $\begin{array}{l}\text { Nilai } \\
\text { Rata-rata }\end{array}$ & $\begin{array}{l}\text { Nilai } \\
\text { Maks }\end{array}$ \\
\hline 1 & PO1 & 2,40 & 5 \\
\hline 2 & PO10 & 2,40 & 5 \\
\hline 3 & AI1 & 2,62 & 5 \\
\hline 4 & DS4 & 2,49 & 5 \\
\hline 5 & ME2 & 2,83 & 5 \\
\hline
\end{tabular}

Sehingga hasil dari rata - rata nilai pada maturity level yaitu 2,55 artinya sistem sudah berada pada Defined level Pada level ini, proses standar dalam pengembangan suatu produk baru didokumentasikan, proses ini didasari pada proses pengembangan produk yang telah diintegrasikan. Dari seluruh data nilai diatas disimpulkan bahwa kekurangan pada DPRD Sijunjung ini ada pada PO1 dan PO10 yaitu bagian dari Planning and Organization sehingga harus lebih dikembangkan lagi dan 
kelebihannya berada pada ME2 yaitu bagian Monitoring and Evaluation.

Testing untuk mengetahui kesalahan dalam hasil pengukuran kualitas sistem. Pengujian terhadap sistem dilakukan untuk dapat mengukur kualitas sistem pelayanan terhadap karyawan yang ada pada DPRD Sijunjung

\section{Menu Halaman Responden}

Tampilan sistem informasi penentuan kulialitas sistem yang ada pada DPRD Sijunjung. Adapun bentuk tampilan Menu Halaman Responden dapat dilihat pada gambar 2.

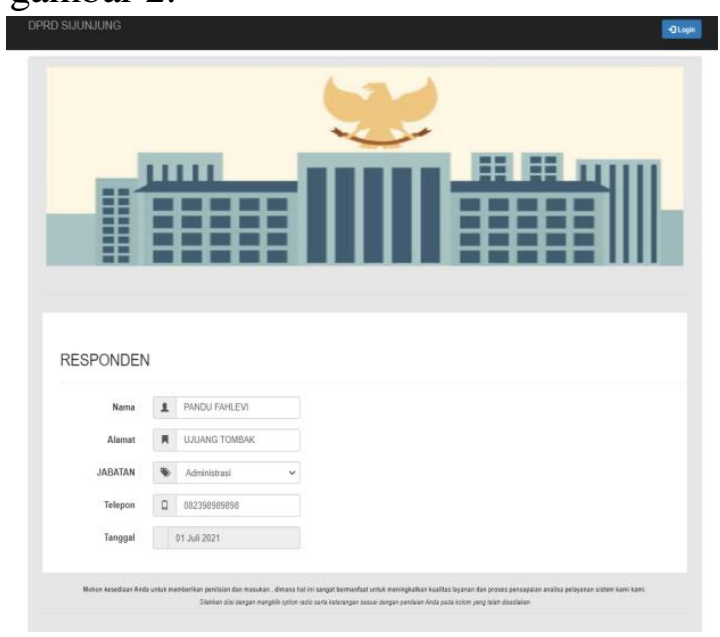

Gambar 2. Menu Halaman Responden

\section{Menu Halaman Login}

Menu halaman Login pada Sistem informasi penentuan kulialitas sistem yang ada pada DPRD Sijunjung. Adapun bentuk tampilan Menu halaman Login dapat dilihat pada gambar 3 .

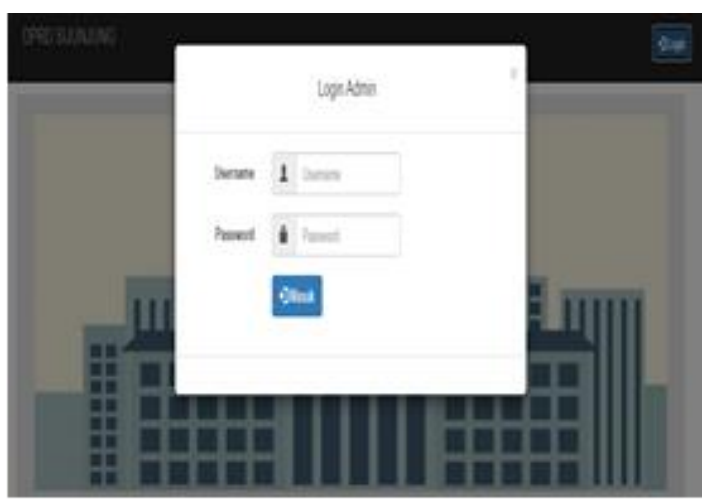

\section{Gambar 3. Menu Halaman Login}

\section{Menu Halaman Deskripsi}

Bentuk tampilan sistem informasi penentuan kulialitas sistem yang ada pada DPRD Sijunjung. Adapun bentuk tampilan Menu Halaman Deskripsi dapat dilihat pada gambar 4 .

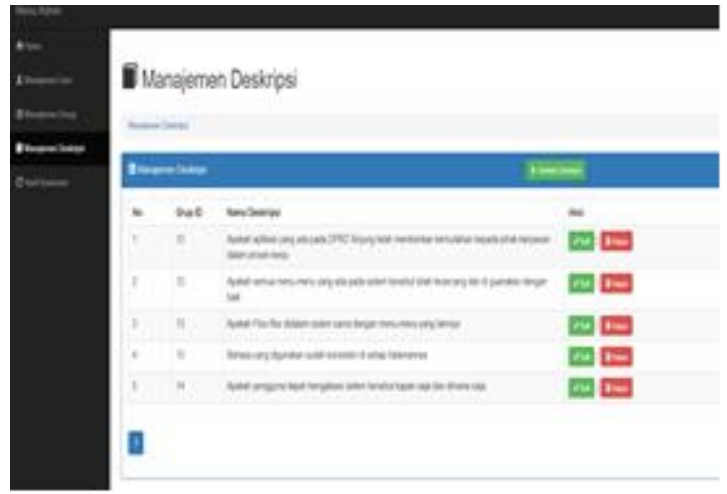

\section{Gambar 4. Menu Halaman Deskripsi}

\section{Menu Managemen Group}

Tampilan Menu Managemen Group sistem informasi penentuan kulialitas Adapun bentuk tampilan Menu Managemen Group dapat dilihat pada gambar 5.

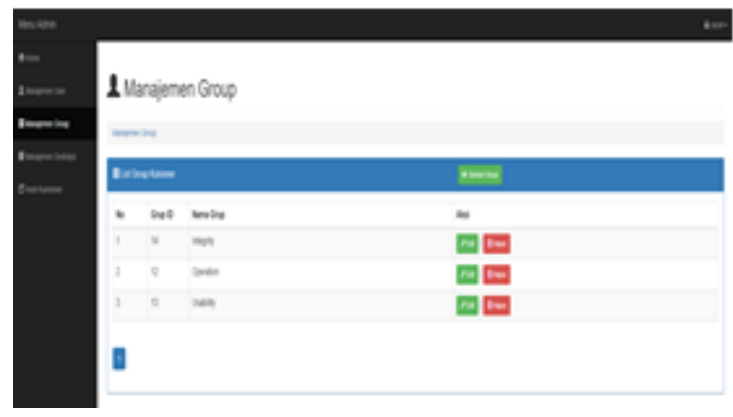

Gambar 5. Menu Managemen Group

\section{Menu Hasil Kuisoner}

Tampilan Menu Hasil Kuisoner sistem informasi penentuan kulialitas sistem. Adapun bentuk tampilan Menu Hasil Kuisoner dapat dilihat pada gambar 6 . 


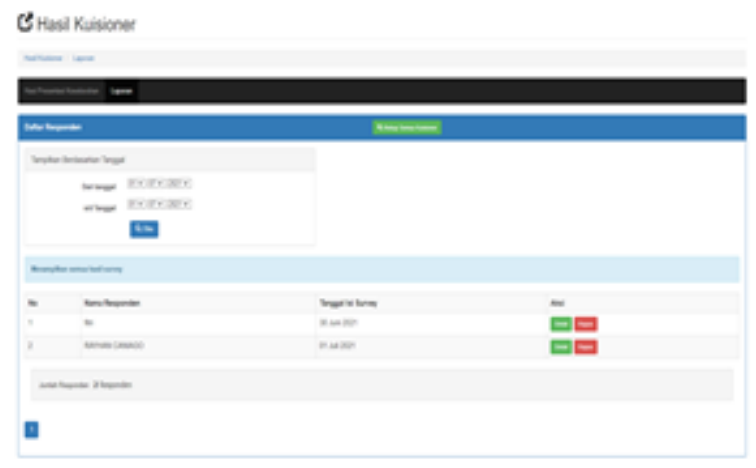

Gambar 6. Menu Hasil Kuisoner

\section{Menu Laporan}

Tampilan Menu Laporan sistem informasi penentuan kulialitas sistem yang ada pada DPRD Sijunjung. Adapun bentuk tampilan sistem Menu Laporan dapat dilihat pada gambar 7 .

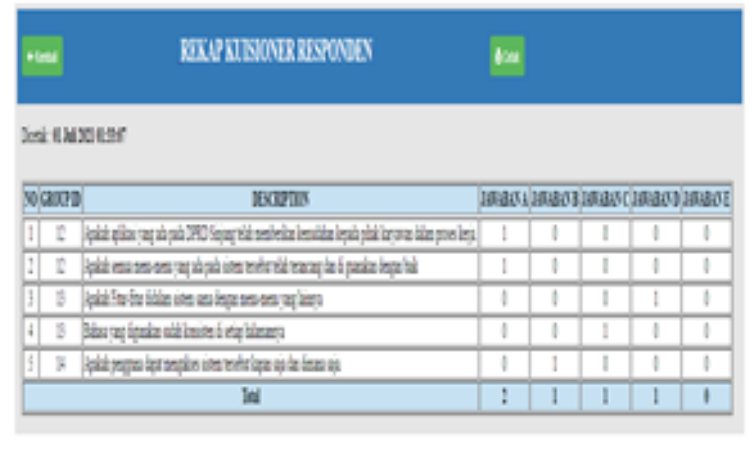

Gambar 7. Menu Laporan

\section{SIMPULAN}

Berdasarkan hasil penelitian yang telah dilakukan maka dapat ditarik kesimpulan sebagai berikut :

1. Hasil analisa pengelolaan teknologi sistem informasi manajemen terhadap tingkat kepuasan yang diterapkan pada DPRD Sijunjung menghasilkan suatu hasil analisis maturity level kesimpulan cukup memuaskan.

2. Setelah diketahui alur kerja dari sistem informasi aplikasi yang digunakan maka dapat membuat sistem lebih terorganisir dan mempermudah berjalannya suatu sistem karena telah diketahui bagaimana tingkat kematangan dari sistem yang diterapkan dan dapat memberikan prioritas perkembangan berikutnya.

3. Pada level prosedur sistem informasi manajemen telah berjalan dengan baik menurut user pengguna sistem sendiri. Sistem telah distandardisasikan, didokumentasikan,serta dikomunikasikan melalui pelatihan kepada setiap pengguna sistem. Namun, implementasinya diserahkan pada setiap individu, sehingga kemungkinan penyimpangan tidak dapat dideteksi. Prosedur tersebut dikembangkan sebagai bentuk formulasi dari praktik yang ada dan kondisi yang diharapkan memiliki nilai 4 sehingga menjadi level 4 (Managed).

\section{.UCAPAN TERIMAKASIH}

Ucapan terima kasih kami kepada pihak yang telah membantu dalam memberikan dukungan terhadap penelitian ini.

\section{DAFTAR PUSTAKA}

Abdurahman, M. 2018. Sistem Informasi Data Pegawai Berbasis Web Pada Kementerian Kelautan Dan Perikanan Kota Ternate. Jurnal Ilmiah ILKOMINFO - Ilmu Komputer \& Informatika 1(2),70-78.

Adolong, N., Mokodongan, R., Penanaman Modal dan Pelayanan Terpadu Satu Pintu Jln Baharrudin J Habibie, B. D. \& Bone Bolango, K. 2017. Implementasi Tata Kelola Teknologi Informasi menggunakan Framework COBIT 5 di BPMPTSP Bone Bolango Implementasi Tata Kelola Teknologi Informasi Menggunakan Framework Cobit 5 di 
BPMPTSP Bone Bolango IT Governance Implementation using COBIT 5 Framework in B. Jurnal Masyarakat Telematika dan Informasi 8(2): 109-126.

Andry Jeffry; Khotama, Michael; Chandra, Agustinus; Gunawan, Catherine Kurniadi, J. F. O. 2018. Audit Fingerprint pada PT X dengan Framework COBIT 4.1. Jurnal Informatika dan Sistem Informasi 04(Vol 4 No 1 (2018): Jurnal Informatika dan Sistem Informasi): 34-43. Retrieved from https://journal.uc.ac.id/index.php/JUI SI/article/view/693

Eva Zuraidah. 2020. Audit tata kelola teknologi informasi menggunakan framework cobit 4.1 (pada studi kasus pt anugerah). jurnal PROSISKO 07(01): 84-95. Retrieved from https://ejurnal.lppmunsera.org/index.php/PR OSISKO/article/view/2289

Fauzan, R., \& Latifah, R. 2015. AUDIT TATA KELOLA TEKNOLOGI INFORMASI UNTUK MENGONTROL MANAJEMEN KUALITAS MENGGUNAKAN COBIT 4.1 PADA PT NIKKATSU ELECTRIC WORKS. Jurnal Teknik Informatika Dan Sistem Informasi Vol 1 No 3: 10-17. doi:https://doi.org/10.28932/jutisi.v1 i3.593

Hadi, F. F. H. \& Gushelmi, G. 2021. Sistem Pengambilan Keputusan Pemilihan Siswa Yang Berhak Mendapatkan Beasiswa Miskin
Dengan Metode Analytical Hierarchy Process (Ahp). Jurnal Teknologi Dan Sistem Informasi Bisnis 3(1): 157-166. doi:10.47233/jteksis.v3i1.173

Hakim, A., Saragih, H. \& Suharto, A. 2014. Jurnal Sistem Informasi ( Journal of Information Systems ). 2 / 10 ( 2014$), 83-86$ DOI : http://dx.doi.org/10.21609/jsi.v10i2. 390. Jurnal Sistem Informasi 10(2): 83-86.

Hapsari, S. W., Aknuranda, I. \& Rokhmawati, R. I. 2018. Implementasi Tata Kelola Teknologi Informasi Berdasarkan Framework COBIT 5 Pada PT Krakatau Tirta Industri. Jurnal Pengembangan Teknologi Informasi dan Ilmu Komputer (J-PTIIK) Universitas Brawijaya 2(11): 5726-5732.

Hilmawan, H., Nurhayati, O. D. \& Windasari, I. P. 2015. Analisis Tata Kelola Teknologi Informasi menggunakan Kerangka Kerja COBIT 5 pada AMIK JTC Semarang. Jurnal Teknologi dan Sistem Komputer 3(2): 247. doi:10.14710/jtsiskom.3.2.2015.247252

Teknologi, J., Sistem, D., Bisnis, I., Teknologi, S. D., Islam, U., Sultan, N., Kasim, S., et al. 2021. RANCANG BANGUN SISTEM PENDATAAN HARDWARE 3(2): 412-418. 